Proceedings

\title{
Can Species Distributions Models Help to Design Conservation Strategies for Narrow-Ranged Species under Climate Change? A Case Study from Santolina Genus ${ }^{\dagger}$
}

\author{
Lucia Varaldo 1,*, Davide Davide ${ }^{1}$, Maria Guerrina ${ }^{1}$, Luigi Minuto ${ }^{1}$, Fabio Conti ${ }^{2}$, Fabrizio Bartolucci ${ }^{2}$ and \\ Casazza Gabriele ${ }^{1}$
}

Citation: Varaldo, L.; Davide, D.; Guerrina, M.; Minuto, L.; Conti, F.; Bartolucci, F.; Gabriele, C. Can Species Distributions Models Help to Design Conservation Strategies for Narrow-Ranged Species under Climate Change? A Case Study from Santolina Genus. Proceedings 2021, 68, x. https://doi.org/10.3390/xxxxx

Published: date

Publisher's Note: MDPI stays neutral with regard to jurisdictional claims in published maps and institutional affiliations.

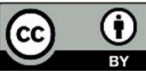

Copyright: $₫ 2021$ by the authors. Submitted for possible open access publication under the terms and conditions of the Creative Commons Attribution (CC BY) license (http://creativecommons.org/licenses/by/4.0/).
1 Department for the Earth, Environment and Life Sciences (DISTAV), University of Genoa, Corso Europa 26, 16132 Genoa, Italy; dagnino.botanica@gmail.com (D.D.); maria.guerrina@edu.unige.it (M.G.); luigi.minuto@unige.it (L.M.); gabriele.casazza@unige.it (C.G.)

2 Centro Ricerche Floristiche dell'Appennino, Scuola di Bioscienze e Medicina Veterinaria, Univ. di Camerino-Parco Nazionale del Gran Sasso e Monti della Laga, San Colombo, Barisciano, L'Aquila, Italy;

* Correspondence: lucia.varaldo@edu.unige.it

+ Presented at the 1st International Electronic Conference on Biological Diversity, Ecology and Evolution, 1531 March 2021; Available online: https://bdee2021.sciforum.net/.

\begin{abstract}
Climate change is dramatically threatening biodiversity. Narrowly distributed species are especially exposed to extinction risk due to their narrow ecological niche. We used Species Distribution Models at fine spatial resolution $(50 \mathrm{~m})$ to investigate changes in the distribution of three range-restricted species of Santolina (Asteraceae) endemic to the Mediterranean Basin (S. decumbens, S. ligustica, S. pinnata). We assessed the future potential range under an optimistic and a pessimistic scenario, and analysed distribution change taking into account three different areas: the distributional range (calculated as convex hull), an area $5 \mathrm{~km}$ larger than the distributional range, and a buffer $(1 \mathrm{~km})$ around occurrences. Santolina ligustica is expected to dramatically reduce its range under both scenarios, $S$. decumbens is expected to increase its range under both scenarios and $S$. pinnata is expected to dramatically reduce its range under pessimistic scenario and to increase it under optimistic one. Moreover, under the optimistic scenario, S. ligustica and S. pinnata show a very high range loss in all areas but the range gain is major in the largest area than in the other two areas. This result suggests that, in the future, suitable areas will occur mainly outside of the current distributional range and that assisted colonization might be necessary to assure species survival. Differently the third species has a lower range loss and higher range gain within the distributional range and in the buffer around occurrences, suggesting the possibility of survival in microrefugia within its distributional range despite a wide reduction in suitable habitat. These results might help to design strategies for species conservation in face of future climate change.
\end{abstract}

Keywords: biodiversity; Species Distribution Models; conservation

\section{Introduction}

Climate change is increasingly affecting the distribution of species, particularly those who have a narrow distributional range [1-4]. These small-ranging species are in double jeopardy because they have a great intrinsic vulnerability to stochastic disturbances due to their low population size and a limited ability to escape warming because of poor dispersal capability [5]. Consequently, in situ protection of natural habitats may be inadequate to reduce the loss of populations in narrow range species because of the velocity of human-induced climate change [6]. Therefore, it may be necessary to move individuals into new suitable areas, likely not reachable by endemic taxa due to their dispersal limitations. However, the survival rate of translocated plants is generally low mainly because 
of the release in unsuitable habitat $[7,8]$. Thus, to conserve small-ranging species it is necessary not only to assess their vulnerability to climate warming, but also to understand where suitable areas will occur in the future in order to detect optimal locations for reintroductions and to maximize the success rate.

Nowadays species distribution models (SDMs) are a broadly used statistical tool to forecast the impact of climate change on biodiversity [9]. Nevertheless, until now their applications to translocation planning have been scarce.

The Mediterranean Basin is one of the main world biodiversity hotspots and it is particularly rich in endemic species [10,11]. Santolina genus (Asteraceae) is widespread throughout the Mediterranean Sea. It includes 24 species, several of which are endemic. In this study we selected S. decumbens Mill., S. ligustica Arrigoni and S. pinnata Viv., three species with a narrow distribution range, endemic to the North Tyrrhenian area from Provence to Tuscany.

We used SDMs to analyze the potential effects of climate change on these three narrow range species of Santolina. To assess the possibility of assisted translocation, we evaluated the occurrence of suitable areas at different distance from the currently known distribution of the species.

\section{Materials and Methods}

The three selected Santolina species are characterized by a relatively high number of occurrences in a restricted area. Santolina decumbens is endemic to Southern France, located in the South East of France (Provence), S. ligustica and S. pinnata are Italian endemisms, located in the North West of Italy (Liguria and Tuscany). Santolina decumbens grows in dry fields and garrigue on basic rocky soils, alluvial deposits, marls and silty soil between 10 and $1025 \mathrm{~m}$ a.s.l. [12]. Santolina ligustica grows in garrigue, slopes and rocky fields on ophiolitic substrates between the sea and $650 \mathrm{~m}$ a.s.l. [13]. Santolina pinnata grows on sunny cliffs, rocks and limestone soils between 500 and $1500 \mathrm{~m}$ a.s.l. [14-16].

Occurrence data were obtained from local database [17] and from the project "PLAN.T.S. 2.0-towards a renaissance of PLANt Taxonomy and Systematics". We took into account only occurrences detected using a GPS tracker.

We downloaded 19 bioclimatic variables both for the present and the future (2080) from CHELSA climate database website [18] at of 30-s $(\sim 1 \mathrm{~km})$ spatial resolution. We selected, among those available, the most optimistic scenario-named rcp26-and the most pessimistic one - named rcp85. To take into account microclimatic conditions [19], we statistically downscaled bioclimatic variables at $50 \mathrm{~m}$ spatial resolution using a physiographically informed model fitted with a geographically weighted regression (GWR). We used the following physiographic variables derived from a digital elevation model downloaded from the CGIAR-CSI GeoPortal website [20]: distance of the sea, slope, north exposition and south exposition. We then used the first two axes of the Principal Component Analysis (PCA) as environmental variables for species distribution modelling in order reduce the transferability issue [21]. We calculated the PCA using "ade4" package implemented in $\mathrm{R}$ [22].

In order to account among algorithms variability in the modelling process [23], we selected six algorithms included in "BIOMOD2" package [24] and implemented in R [22]: generalized linear model (GLM) [25]; classification tree analysis (CTA) [26]; flexible discriminant analysis (FDA) [27]; generalized boosted models (GBM) [28]; random forest (RF) [29]; multivariate adaptive regression splines [30]. For pseudo-absence selection we followed the indication of Barbet-Massin et al. [31], using different settings to obtain the higher evaluations of the models. Model performance was evaluated using two different measures: ROC [32] and TSS [33].

We converted the continuous probability values into binary presence-absence form. To reduce the possibility of prediction bias linked by the choice of the threshold, we used three different thresholds implemented in the PresenceAbsence package [34], performing equally or better than others [35]. Following the majority consensus rule, we considered 
the species as occurring in a cell only if the model predicts at least $50 \%$ of its presence there.

To assess the position of possible area for translocation in relationship to the species distribution, we considered three different ranges: the distributional range (calculated as convex hull), an area $5 \mathrm{~km}$ larger than the distributional areas, and a buffer $(1 \mathrm{~km})$ around occurrences. For all these three cases, we calculated the number of currently suitable cells. Moreover, we calculated: the number of cells that will remain suitable (range stable); the number of cells that will no longer be suitable (range loss); and the number of cells that are not currently suitable but that will be suitable under future climate (range gain). Lastly, we calculated range change, which is based on the number of potential cells gained or lost [36].

\section{Results and discussion}

According to the thresholds established from Araujo et al. [37], under current climate scenario, all modelling algorithms had a good model performance ranging from 0.6 to 0.95 .

\subsection{Future Impacts of Climate Change on the Distribution of Santolina Species}

The three species are projected to have a range loss higher in pessimistic than in optimistic scenario, even if they will be probably affected differently by climate change (Tables 1 and 2). In fact, $S$. decumbens will probably increase its distributional range under the optimistic scenario and will moderately contract it under pessimistic one. Santolina pinnata will expand its distributional range under the optimistic scenario and will lose all the climatically suitable areas under the pessimistic. Lastly, S. ligustica will lose a high percentage of its current potential range under both scenarios (Tables 1 and 2).

Table 1. Percentage of range loss (RL), range gain (RG) and range change (RC) under future optimistic scenario for the three studied taxa. For each species, range dynamic was calculated in three different areas: the distributional range (DR), an area $5 \mathrm{~km}$ larger than the distributional range $(w D R)$, and a $1 \mathrm{~km}$ buffer around occurrences (Bf).

\begin{tabular}{|c|c|c|c|}
\hline & S. decumbens & S. ligustica & S. pinnata \\
\hline$\% R G w D R$ & 46 & 145.59 & 128.28 \\
\hline$\% R L w D R$ & 0.55 & 73.75 & 0 \\
\hline$\%$ change $w D R$ & 45.46 & 145.59 & 128.28 \\
\hline$\% R G D R$ & 61.63 & 16.55 & 49.9 \\
\hline$\% R L D R$ & 0.06 & 70.97 & 0 \\
\hline$\% R C D R$ & 61.57 & -54.42 & 49.9 \\
\hline$\% R G B f$ & 65.45 & 12.17 & 50.85 \\
\hline$\% R L B f$ & 0.11 & 76.05 & 0 \\
\hline$\% R C B f$ & 65.34 & -63.88 & 50.85 \\
\hline
\end{tabular}

Table 2. Percentage of range loss (RL), range gain (RG) and range change (RC) under future pessimistic scenario for the three studied taxa. For each species range dynamic was calculated in three different areas: the distributional range (DR), an area $5 \mathrm{~km}$ larger than the distributional range (wDR), and a $1 \mathrm{~km}$ buffer around occurrences (Bf).

\begin{tabular}{cccc}
\hline & S. decumbens & S. ligustica & S. pinnata \\
\hline$\%$ RG wDR & 24.05 & 0 & 0.23 \\
$\%$ RL wDR & 47.51 & 100 & 100 \\
$\%$ change wDR & -23.46 & -100 & $-99-77$ \\
$\%$ RG $D R$ & 45.15 & 0 & 0.01 \\
$\%$ RL $D R$ & 38.16 & 100 & 100 \\
$\%$ RC $D R$ & 6.99 & -100 & -99.99 \\
$\% R G B f$ & 21.77 & 0 & 0.03
\end{tabular}




\begin{tabular}{lccc}
$\% R L B f$ & 18.92 & 100 & 100 \\
$\% R C B f$ & 2.86 & -100 & -99.97 \\
\hline
\end{tabular}

The difference between the two scenarios is in line with the observation that climate projected under optimistic scenario fall within the climatic variability that species already experienced during the Holocene [38,39]. Despite range contraction seems to be the main trend under future climate [40], potential range expansion under a moderate global warming, as observed in S. decumbens, was previously observed in other Mediterranean thermophilus species [41,42]. The different trends detected in the three species is in line with the idea that species sensitivity to climate change is affected by niche properties and the difference between current and future climate in which species grow [43]. In fact, the two species with the narrow altitudinal range (i.e., S. ligustica and S. pinnata) seem to be more threatened by climate change than $S$. decumbens which has a wider altitudinal range. This is likely due to the temperature increase which will remain within the climatic conditions already experienced by populations at lower altitudes. Moreover, under the pessimistic scenario we projected a lower extinction risk in S. decumbens than detected by Dagnino et al. [43], using in our study a finer resolution. This result supports the idea that local microrefugia may play a role in holdout to species extinction under future climate change [44]. Moreover, as already suggested by previous studies [44,45], S. ligustica may be also threatened by urbanization besides climate change, further increasing its risk of extinction.

\subsection{Differences in Range Change among Areas}

Under the optimistic scenario, in S. ligustica and S. pinnata the range gain is higher in the largest areas (i.e., $145 \%$ and $128 \%$ vs. $16 \%$ and $50 \%$ ) differently to $S$. decumbens, which will gain more suitable cells in the two narrow areas (i.e., $61 \%$ and $65 \%$ vs. $46 \%$; Table 1 ). Similarly, under pessimistic scenario the range loss in S. ligustica and S. pinnata is higher in all the three areas, while $S$. decumbens will loss part of suitable range considering the $\mathrm{wDR}$ area but will gain suitable range considering the Bf area (Table 2). This result suggests that future suitable areas for S. ligustica and S. pinnata would not be close to the current occurrences, differently to $S$. decumbens. The ability of species to cope with the climate change is affected by the possibility to reach new suitable areas that is, in turn, related to the location of suitable areas and dispersal capability [40]. Santolina has a poor dispersal capability having seeds with a low efficient plume [46]. Consequently, S. ligustica and S. pinnata, the two species for which future suitable areas would not be close to the current occurrences, might not be able to migrate fast enough to counteract climate change. For these species, the assisted colonization should be considered as a proactive conservation activity [47]. Differently, in S. decumbens, which is projected to have suitable cells near the occurrences, conservation strategy may be built around microrefugia (both ephemeral and stable) and stepping-stones [48,49].

\section{Conclusions}

The reduction forecasted for the three species underlines the serious potential impact of climate change in the north Mediterranean area. Taken together, our results suggest that some Mediterranean species may generally be favored by future climate change. This is the case of $S$. decumbens, the species with the widest altitudinal range, which would shift its distributional range. The other two species (S. ligustica and S. pinnata), with a narrow altitudinal range, would be not able to adjust their geographic distribution appropriately, and, in turn, would be more affected by the climate change. In S. pinnata the persistence of suitable area close to the current distribution would allow in situ conservation and translocation. Differently in S. ligustica, for which future suitable areas would be outside of the current distributional range, it would be necessary to carry out assisted colonization. Our study underlines the importance of SDMs as tool to design strategies for species 
conservation in face of future climate change. SDMs may provide a cost-benefit tool for planning assisted colonization and conservation translocation.

\section{References}

1. Bellard, C.; Bertelsmeier, C.; Leadley, P.; Thuiller, W.; Courchamp, F. Impacts of climate change on the future of biodiversity. Ecol. Lett. 2012, 15, doi:10.1111/j.1461-0248.2011.01736.x.

2. Cahill, A.E.; Aiello-Lammens, M.E.; Caitlin Fisher-Reid, M.; Hua, X.; Karanewsky, C.J.; Ryu, H.Y.; Sbeglia, G.C.; Spagnolo, F.; Waldron, J.B.; Warsi, O.; et al. How does climate change cause extinction? Proc. R. Soc. B. Biol. Sci. 2013, 280, doi:10.1098/rspb.2012.1890.

3. Moritz, C.; Agudo, R. The future of species under climate change: Resilience or decline? Science 2013, 341, doi:10.1126/science.1237190.

4. Sax, C.; Steiner, P. Temporal disaggregation of time series. R J. 2013, 5, doi:10.32614/rj-2013-028.

5. Sunday, J.M.; Pecl, G.T.; Frusher, S.; Hobday, A.J.; Hill, N.; Holbrook, N.J.; Edgar, G.J.; Stuart-Smith, R.; Barrett, N.; Wernberg, T.; et al. Species traits and climate velocity explain geographic range shifts in an ocean-warming hotspot. Ecol. Lett. 2015, 18, doi:10.1111/ele.12474.

6. Heywood, V.H. Plant conservation in the Anthropocene-Challenges and future prospects. Plant. Divers. 2017, 39, doi:10.1016/j.pld.2017.10.004.

7. Godefroid, S.; Vanderborght, T. Plant reintroductions: The need for a global database. Biodivers. Conserv. 2011, 20, doi:10.1007/s10531-011-0120-2.

8. Dalrymple, S.E.; Banks, E.; Stewart, G.B.; Pullin, A.S. A meta-analysis of threatened plant reintroductions from across the globe. In Plant Reintroduction in a Changing Climate: Promises and Perils; Island Press: Washington, DC, USA, 2012; doi:10.5822/978-161091-183-2_3.

9. Guisan, A.; Tingley, R.; Baumgartner, J.B.; Naujokaitis-Lewis, I.; Sutcliffe, P.R.; Tulloch, A.I.T.; Regan, T.J.; Brotons, L.; McDonald-Madden, E.; Mantyka-Pringle, C.; et al. Predicting species distributions for conservation decisions. Ecol. Lett. 2013, 16, doi:10.1111/ele.12189.

10. Médail, F.; Quézel, P.; Besnard, G.; Khadari, B. Systematics, ecology and phylogeographic significance of Olea europaea L. ssp. maroccana (Greuter \& Burdet) P. Vargas et al., a relictual olive tree in south-west Morocco. Bot. J. Linn. Soc. 2001, 137, doi:10.1006/boj1.2001.0477.

11. Medail, F.; Quezel, P. Biodiversity hotspots in the Mediterranean Basin: Setting global conservation priorities. Conserv. Biol. 1999, 13, doi:10.1046/j.1523-1739.1999.98467.x.

12. Pires, M.; Pavon, D. La Flore Remarquable de la Bouche-du-Rhone: Plantes, Milieux Naturels et Paysage; Biotope Editions: Mèze, France, 2018.

13. Pignatti, S. Flora d'Italia; Edagricole: Bologna, Italy, 2018; Volume 3.

14. Ferrarini, E. Carta della vegetazione delle alpi apuane e zone limitrofe: Note illustrative. Webbia 1973, 27, doi:10.1080/00837792.1973.10669986.

15. Barbero, M.; Bono, G. La végétation orophile des Alpes apuanes. Vegetatio 1973, 27, doi:10.1007/BF02389339.

16. Arrigoni, P.V.; Santolina, L. Flora d'Italia, 1st ed.; Pignatti, S., Ed.; Edagricole: Bologna, Italy, 2018; Volume 3, pp. 64-65.

17. Système d'Information et de Localisation des Espèces Natives et Envahissantes (SILENE). Conservatoire Botanique National de Porquerolles, France. Available online: http://flore.silene.eu/index.php?cont=accueil (accessed on January 2020).

18. Climatologies at High Resolution for the Earth's Land Surface Areas (CHELSA). Available online: http://chelsa-climate.org/ (accessed on January 2020).

19. Benestad, R.E. Empirical-statistical downscaling in climate modeling. Eos 2004, 85, doi:10.1029/2004EO420002.

20. CGIAR-CSI GeoPortal. Available online: https://srtm.csi.cgiar.org/ (assessed on January 2020).

21. Petitpierre, B.; Broennimann, O.; Kueffer, C.; Daehler, C.; Guisan, A. Selecting predictors to maximize the transferability of species distribution models: Lessons from cross-continental plant invasions. Glob. Ecol. Biogeogr. 2017, 26, doi:10.1111/geb.12530.

22. R Core Team. R: A Language and Environment for Statistical Computing; R Core Team: Vienna, Austria, 2017; Available online: http//www R-project org/ (accessed on).

23. Araújo, M.B.; Luoto, M. The importance of biotic interactions for modelling species distributions under climate change. Glob. Ecol. Biogeogr. 2007, 16, doi:10.1111/j.1466-8238.2007.00359.x.

24. Thuiller, W.; Lafourcade, B.; Engler, R.; Araújo, M.B. BIOMOD-A platform for ensemble forecasting of species distributions. Ecography 2009, 32, doi:10.1111/j.1600-0587.2008.05742.x.

25. McCullagh, P.; Little, W.S. A Comparison of Modalities in Modeling. Hum. Perform. 1989, 2, doi:10.1207/s15327043hup0202_2.

26. Breiman, L.; Friedman, J.H.; Olshen, R.A.; Stone, C.J. Classification and Regression Trees; Routledge: Boca Raton, FL, USA, 1984; doi:10.1201/9781315139470.

27. Hastie, T.; Tibshirani, R.; Buja, A. Flexible discriminant analysis by optimal scoring. J. Am. Stat. Assoc. 1994, 89, doi:10.1080/01621459.1994.10476866.

28. Ridgeway, G. The state of boosting. Comput. Sci. Stat. 1999, 31.

29. Breiman, L. Statistical modeling: The two cultures. Stat. Sci. 2001, 16, doi:10.1214/ss/1009213726.

30. Friedman, J. Fast MARS; Technical Report LCS110; Department of Statistics, Stanford University: Stanford, CA, USA, 1993. 
31. Barbet-Massin, M.; Jiguet, F.; Albert, C.H.; Thuiller, W. Selecting pseudo-absences for species distribution models: How, where and how many? Methods Ecol. Evol. 2012, 3, doi:10.1111/j.2041-210X.2011.00172.x.

32. Hanley, J.A.; McNeil, B.J. The meaning and use of the area under a receiver operating characteristic (ROC) curve. Radiology 1982, 143, doi:10.1148/radiology.143.1.7063747.

33. Allouche, O.; Tsoar, A.; Kadmon, R. Assessing the accuracy of species distribution models: Prevalence, kappa and the true skill statistic (TSS). J. Appl Ecol. 2006, 43, doi:10.1111/j.1365-2664.2006.01214.x.

34. Moisen, G.; Freeman, E. PresenceAbsence: An R Package for Presence Absence Analysis. J. Stat. Softw. $2008,23,16729$.

35. Cao, Y.; DeWalt, R.E.; Robinson, J.L.; Tweddale, T.; Hinz, L.; Pessino, M. Using Maxent to model the historic distributions of stonefly species in Illinois streams: The effects of regularization and threshold selections. Ecol. Modell. 2013, 259, doi:10.1016/j.ecolmodel.2013.03.012.

36. Thuiller, W. Patterns and uncertainties of species' range shifts under climate change. Glob. Chang. Biol. 2004, 10, doi:10.1111/j.1365-2486.2004.00859.x.

37. Araujo, M.; Pearson, R.; Thuiller, W.; Erhard, M. Validation of species-climate impact models under climate change. Glob. Chang. Biol. 2005, 11, doi:10.1111/j.1365-2486.2005.001000.x.

38. Guiot, J.; Cramer, W. Climate change: The 2015 Paris Agreement thresholds and Mediterranean basin ecosystems. Science 2016, 354, doi:10.1126/science.aah5015.

39. Fauquette, S.; Suc, J.P.; Médail, F.; Muller, S.D.; Jiménez-Moreno, G.; Bertini, A.; Martinetto, E.; Popescu, S.; Zheng, Z.; de Beaulieu, J. The Alps: A geological, climatic and human perspective on vegetation history and modern plant diversity. Mt. Clim. Biodivers. 2018, 27, 413-428.

40. Engler, R.; Randin, C.F.; Vittoz, P.; Czáka, T.; Beniston, M.; Zimmermann, N.E.; Guisan, A. Predicting future distributions of mountain plants under climate change: Does dispersal capacity matter? Ecography 2009, 32, doi:10.1111/j.1600-0587.2009.05789.x.

41. Esteve-Selma, M.A.; Martínez-Fernández, J.; Hernández-García, I.; Montávez, J.P.; López-Hernández, J.J.; Calvo, J.F. Potential effects of climatic change on the distribution of Tetraclinis articulata, an endemic tree from arid Mediterranean ecosystems. Clim. Change 2012, 113, doi:10.1007/s10584-011-0378-0.

42. Casazza, G.; Giordani, P.; Benesperi, R.; Foggi, B.; Viciani, D.; Filigheddu, R.S.; Farris, E.; Bagella, S.; Pisanu, S.; Mariotti, M.G. Climate change hastens the urgency of conservation for range-restricted plant species in the central-northern Mediterranean region. Biol. Conserv. 2014, 179, doi:10.1016/j.biocon.2014.09.015.

43. Dagnino, D.; Guerrina, M.; Minuto, L.; Mariotti, M.G.; Médail, F.; Casazza, G. Climate change and the future of endemic flora in the South Western Alps: Relationships between niche properties and extinction risk. Reg. Environ. Chang. 2020, 20, doi:10.1007/s10113-020-01708-4.

44. Conti, F.; Manzi, A.; Pedrotti, F. Libro Rosso delle Piante d'Italia; WWF Italia: Roma, Italy, 1992.

45. Torricelli, C.; Garbari, F.; Bedini, G. () Santolina ligustica (Compositae), specie da proteggere della flora ligure, 1999. In Atti della Società Toscana di Scienze Natutali, Memorie; Serie B; Biodiversity Heritage Library: 2000; Volume 106, pp. 1-7.

46. Vittoz, P.; Engler, R. Seed dispersal distances: A typology based on dispersal modes and plant traits. Bot. Helv. 2007, 117, doi:10.1007/s00035-007-0797-8.

47. Butt, N.; Chauvenet, A.L.M.; Adams, V.M.; Beger, M.; Gallagher, R.V.; Shanahan, D.F.; Ward, M.; Watson, J.E.M.; Possingham, H.P. Importance of species translocations under rapid climate change. Conserv. Biol. 2020, doi:10.1111/cobi.13643.

48. Randin, C.F.; Engler, R.; Normand, S.; Zappa, M.; Zimmermann, N.E.; Pearman, P.B.; Vittoz, P.; Thuiller, W.; Guisan, A. Climate change and plant distribution: Local models predict high- elevation persistence. Glob. Chang. Biol. 2009, 15, doi:10.1111/j.13652486.2008.01766.x.

49. Hannah, L.; Flint, L.; Syphard, A.D.; Moritz, M.A.; Buckley, L.B.; McCullough, I.M. Fine-grain modeling of species' response to climate change: Holdouts, stepping-stones, and microrefugia. Trends. Ecol. Evol. 2014, 29, doi:10.1016/j.tree.2014.04.006. 